\title{
The innovation union within the Slovak business environment
}

\author{
Marcel Kordoš * Eva Ivanová \\ Alexander Dubček University in Trenčín, Slovak Republic \\ *Corresponding author: Marcel Kordoš, PhD., marcel.kordos@tnuni.sk
}

\begin{abstract}
This paper deals with the issue how innovation is implemented into EU Innovation policy processes, how important role it plays within the Slovak Business environment to assure the rapid development of SMEs and to enhance Slovak competitiveness within the international economics environment. By means of analysis, comparative analysis methods followed by logical deduction the main goal of this paper is to figure out how and in what way the technology and innovation implementation processes in EU Innovation policy can affect the Slovak Business environment in terms of the social and economic development promotion measurements.
\end{abstract}

Key words: innovation performance; research and development, EU Innovation policy, small and medium enterprises (SMEs), international economics

\section{Introduction and theoretical background}

Innovations are considered to be the driving force of economic and social development of enterprises, regions, national economies, as well as geopolitical integration units. They affect economic growth, employment growth and competitiveness at the regional, national and international levels (P. F. Drucker ${ }^{1}$ ). Research and development is ranked among the key sources of technical innovations that initiate product innovations. An innovation taking the form of new or significantly improved products (technologies or services) effectively placed at the market are the result of a series of scientific, technical, organizational, financial, commercial and other activities (M. Kačirková ${ }^{2}$ ). These activities include research and development. Thus, innovations are the result of effective application of science, research and development in practice.

Innovation is referred to a planned, managed and implemented change in terms of a new system or its better state. In the area of manufacturing companies it is usually all about a new quality product creation and implementation, new production process or new organization methods such as marketing and management. Innovation is an appreciation of creativity and 
invention (D. Vlacseková , L. Mura ${ }^{3}$ ). The main impetus for innovation is usually customer's interest in higher quality, products utility value or research and development results leading to the following four types of innovation: innovation within product, process, organization and marketing (E. Cihelkova, P. Hnat ${ }^{4}$ ).

Innovation can be defined as process by which the company put into practice products and manufacturing processes models being new to them, regardless of being new also in the world. Then we talk about the first product launching by a company on market as well as technology dissemination. Porter also was dealing with the issue of innovation in terms of defining the concept of national competitiveness as a key capability of nation (country) to innovate and hence to gain the competitive advantage (M. E. Porter ${ }^{5}$ ).

The industrial policy of the EU stresses the importance of promoting innovation among European companies as one of the key objectives of policy. This has led to the development of framework policies to promote pan-EU cooperation in R\&D and other areas of technological development (L. Fojtíková ${ }^{6}$ ). The development of a knowledge-based economy lies at the heart of these framework policies. The structuring of the European research area part of the program is seeking to build a European research base and accounts for approximately 16 percent of the budget (J. Tauser et al. ${ }^{7}$ ). The framework programs are basically attempts to build pan-EU competence in major areas of research and technological developments and to promote a European ethos for such a research base. The framework programs have elements of seeking to build European champions in the area of research and technological competence ( $P$. Balaz $\left.^{8}\right)$. The rationale for this would seem to be closely allied to the political integration driver of policy, as it is not clear that a European research and technological development base is preferable to a global or even a US orientated base ( $P$. Hnát ${ }^{9}$ ). The USA is the technological leader in most of the thematic areas, hence linking to US research bases may be a more effective policy (S. M. Obadi, M. Korcek ${ }^{10}$ ).

\section{Goal and methodology}

Within the hypothesis we suppose that the EU Innovation policy and Innovation Union create a proper environment and conditions to enhance the Slovak competitiveness in international economics. The goal of this paper based on the EU Innovation policy and Innovation Union comparison analysis is to figure out their positive impact on the Slovak business and economic environment as the way how to achieve higher social and economic development and living standard of Slovak inhabitants. The issue is to point out the extent to which the EU 
Innovation policy tools and strands implemented in the Innovation Union can mitigate fluctuations in competitiveness of Slovak business environment - especially SMEs, whose sluggish economic performance evokes a negative impact on the socio-economic development of the countries of European Union. To accomplish this goal, methods such as analysis, comparison, synthesis and logical deduction are to be used.

\section{Results and discussions}

Increasing regional competitiveness in terms of Slovak business environment is based on the ability to execute innovation policy objectives in context of national or regional innovation system. National innovation policies that are closely linked to regional innovation policy, and are based on EU innovation policy are supposed to increase competitiveness of regions by means of their innovation performance increase. European Union Innovation policy appears to be an important instrument how to enhance the economic performance because it affects structural policies and structural reforms.

As highlighted by EU Innovation Policy, industry is crucial for EU competitiveness and innovation is a key factor in this regard. Industry accounts for $80 \%$ of Europe's exports. Some $65 \%$ of private sector research and development (R\&D) investment comes from manufacturing. Therefore, industrial modernization in Europe must be broad-reaching and include the successful commercialization of product and service innovations, the industrial exploitation of innovative manufacturing technologies, innovative business models. Studies show that those companies who prioritize innovation are also those who experience the highest increase in turnover (P. Neumann ${ }^{11}$ ). Some $79 \%$ of companies that introduced at least one innovation since 2014 experienced an increase of their turnover by more than $25 \%$ by 2016. Small and medium-sized enterprises are a particular target for innovation policy. The smaller the company is, the more it faces constraints to innovation or to the commercialization of its innovations. Some 63\% of companies with between 1 and 9 employees declared having introduced at least one innovation since 2016, compared to 85\% of companies with 500 employees or more. Some 71\% of companies with between 1 and 9 employees encountered difficulties commercializing their innovations due to a lack of financial resources, compared to $48 \%$ of companies with 500 employees or more. (European Commission ${ }^{12}$ )

Micro, small and medium-sized enterprises are driving forces for the economy of each developed country; they play an important role in national economies development processes. 
Their importance lies in the fact that they can flexibly respond to market demands, contribute to increasing of innovation activities and competitive environment development, they generate employment, are adaptable and responsive to changes in economic environment (M. Mynarzova, H. Stverkova ${ }^{13}$ ). In 2016 of the total number of businesses in Slovakia micro, small and medium-sized enterprises create a 99\% share, they constitute $73.6 \%$ of employment and $52.8 \%$ of the total value added being created (Slovak Statistical Office ${ }^{14}$ ).

Small and medium enterprises (SMEs) in Slovakia are lagging behind their corporate counterparts in the adoption of innovations. The innovation difficulties in SMEs are quite different from those in large firms. Slovak SMEs suffer from 'labor shortages', 'lack of information', 'lack of infrastructure' and 'lack of financial resources', while large firms indicate such difficulties as 'oligopolists', 'needlessness of innovation', 'R\&D department without power" (Slovak Business Agency ${ }^{15}$ ).

Another issue being widely discussed is the importance of innovation for the development of small and medium enterprises, the SMEs development strategy and the overall provision of resources for the growth of SMEs sector. Slovak SMEs lack absorptive capacity and hence technology intermediaries are useful for them. R\&D-related activities may share around a half of a budget of a technology intermediary center and consequently these form an important element of absorptive capacity. Research cooperation and R\&D outsourcing often offer possibilities to complement the internal research resources but they need absorptive capacity and managerial skills of the internal R\&D personnel (S. Vojtovič $\left.{ }^{16}\right)$. Small and medium enterprises have identified as one of the barriers for innovation the lack of innovation infrastructure. Only a small part of small and medium enterprises in Slovakia possesses sufficient capacities as well as know-how for realization of all activities of innovative process, therefore it is needed to fill this gap with services of specialized consulting organizations. The aim is to create effective system of specialized consulting services for support of innovations. Quality of business environment is influenced by many factors. The important one is the level of levies burden. High level of contribution burden within levies in case of small and medium-sized enterprises (SMEs) are very sensitive to changes in business environment which after a certain time are always reflected in quantitative characteristics of this sector $(K$. Haviernikova, H. Strunz ${ }^{17}$ ).

In Slovak conditions firms that receiving direct financial support from the government have more output from R\&D expenditures and that stimulates innovation propensity of the SMEs. And firms that receiving both direct financial support and tax credit facility are superior in 
terms of innovation performance than the firms that do not receive any of the facilities. Government financial support can directly affect the innovation propensity of the SMEs because of financial incentives.

\section{Conclusions}

We arrived to the conclusion that in all developed countries the successful economy is determined by its level of competitiveness, which greatly depends on innovation performance of a particular economy. For enterprises being the main actors of innovation performance it is very important to obtain resources for their innovation activities. In our research we focused on the identification of financial sources within SMEs and on finding out what structure these sources within SMEs are used the most, while taking into account the objectives and instruments of EU innovation policy we assumed that this kind of instrument will be used in SMEs to a large extent.

In this paper we have shown that the rapid internationalization of technology means that firms need to monitor both their domestic and their foreign technological environments. For many industries, technology is of the utmost importance and can determine whether firms prosper or fall by the wayside. That also applies to Slovak business environment. The innovation performance assessment of the Slovak regions made by utilizing a standardized variable and selected innovation performance-related indicators shows that there are significant differences among the regions of the SR.

\section{Acknowledgements}

This paper was supported by the Slovak Ministry of Education's scientific grant VEGA: "Risk management of SMEs in the context of clusters' involvement activities in the Slovak Republic” [Reg. No.: 1/0918/16].

\section{References / Literatura}

1. P. F. Drucker, Postcapitalist Society. New York: HerperCollins Publishers, (1993)

2. M. Kačírková, Formovanie spolupracujúceho regionálneho inovačného prostredia. Bratislava: Ekonomický ústav SAV, (2009)

3. D. Vlacseková , L. Mura, Effect of motivational tools on employee satisfaction in small and medium enterprises. Oeconomia Copernicana, 8(1) (2017) 111-130.

4. E. Cihelkova, P. Hnat, Future of the European Union within the new regionalism context, Politicka ekonomie, 56(1) (2008) 67-79. 
5. M. E. Porter, The Competitive Advantage of Nations. New York: The Free Press, (1990).

6. L. Fojtikova, Performance and growth of the Eurozone export. 17th International conference enterprise and competitive environment 2014, Book Series: Procedia Economics and Finance, Vol. 12, (2014) 154-163.

7. J. Tauser, M. Arltova, P. Zambersky, Czech exports and German GDP: a closer look. Prague Economic Papers, 24(1), (2015) pp. 17-37

8. P. Balaz, International Trade in the World Crisis of the 21st Century, Ekonomicky casopis, 61(10) (2013) 1079-1083

9. P. Hnát, Balance of Payments Imbalances as a Challenge for Economic Governance. Changes in Governance: In the Context of the Global Crisis, (2013) 79-91

10.S. M. Obadi, M. Korcek, The "Revealed" Comparative Advantage and Competitiveness of the EU's International Trade visa vis the USA. Ekonomicky casopis, 64 (5), (2016). 397-422

11. P. Neumann, The impact of structural changes in national economies on globalization character. Globalization and its socio-economic consequences, (2015). 498-504

12. URL: https://ec.europa.eu/growth/industry/innovation_en (29. 6. 2017.)

13. M. Mynarzova, H. Stverkova, Public Support as an Important Factor for Competitiveness of SMEs in the European Union. Aktualne problemy podnikovej sfery 2015, (2015) 452-461

14. URL:http://www.statistics.sk/pls/elisw/metainfo.explorer?cmd=open\&s=1002\&sso=2. (29. 6. 2017.)

15. URL: http://www.sbagency.sk/sites/default/files/msp_v_cislach_v_roku_2016_0.pdf (29. 6. 2017.)

16. S. Vojtovič, The Impact of The Structural Funds on Competitiveness of Small and Medium-Sized Enterprises. Journal of Competitiveness, 8 (4) (2016) 30-45.

17. K. Havierniková, H. Strunz, The comparison of selected methods used for identification of cluster potential in the regions of the Slovak Republic, SGEM conference on political sciences law, finance economics \& tourism: Conference proceedings volume IV. Economic \& tourism, Sofia: STEF92 Technology, (2014) 693-699. 